\title{
Serosurvey of bluetongue, caprine arthritis- encephalitis (CAE) and Maedi-Visna in Barbary sheep (Ammotragus lervia) of a southern Brazilian $\mathbf{z o o}^{1}$
}

\begin{abstract}
Vivien M. Morikawa ${ }^{2,3 *}$, Maysa Pellizzaro ${ }^{2}$, Igor A.D. Paploski ${ }^{4}$, Mariana Kikuti' Maria C.C.S.H. Lara ${ }^{5}$, Liria H. Okuda ${ }^{5}$, Alexander W. Biondo ${ }^{2}$ and Ivan R. Barros Filho ${ }^{2}$

ABSTRACT.- Morikawa V.M., Pellizzaro M., Paploski I.A.D., Kikuti M., Lara M.C.C.S.H., Okuda L.H., Biondo A.W. \& Barros Filho I.R. 2018. Serosurvey of bluetongue, caprine arthritis-encephalitis (CAE) and Maedi-Visna in Barbary sheep (Ammotragus lervia) of a southern Brazilian zoo. Pesquisa Veterinária Brasileira 38(6):1203-1206. Departamento de Medicina Veterinária, Setor de Ciências Agrárias, Universidade Federal do Paraná, Rua dos Funcionários 1540, Cabral, Curitiba, PR 80035-050, Brazil. E-mail: abiondo@ufpr.br

Bluetongue (BT) is an infectious and non-contagious disease of compulsory notification which may affect domestic and wild ruminants, transmitted by Culicoides spp. midges. Despite the high morbidity and mortality in sheep, role of wild animals in the BT cycle remains unclear. Caprine arthritis-encephalitis (CAE) and Maedi-Visna virus (MVV) have been reportedly found in goats and sheep, but not described in wildlife species. Accordingly, serum samples from 17 captive Barbary sheep (Ammotragus lervia) from Curitiba zoo, southern Brazil, were tested for bluetongue, caprine arthritis-encephalitis (CAE) and Maedi-Visna viruses by agar gel immunodiffusion (AGID) and enzyme linked immunosorbent assay (ELISA). Antibodies for bluetongue were observed in 6/17 (35.3\%) Barbary sheep by AGID test and in $7 / 17(41.2 \%)$ by ELISA. All samples were negative for the presence of antibodies against caprine arthritis-encephalitis (CAE) and Maedi-Visna viruses. These findings indicate that Barbary sheep may be infected by bluetongue virus and act as wildlife reservoir in both captive and free-range environments.
\end{abstract}

INDEX TERMS: Bluetongue, caprine arthritis-encephalitis, Maedi-Visna, Barbary sheep, zoos, viroses.

\begin{abstract}
RESUMO.- [Estudo sorológico dos vírus da língua azul, da artrite-encefalite caprina e Maedi-Visna em aoudads (Ammotragus lervia) em um zoológico do Sul do Brasil.] A língua azul é uma doença infecciosa e não contagiosa, de notificação obrigatória, que pode afetar ruminantes domésticos e silvestres, transmitida por mosquitos do gênero Culicoides spp. Apesar da alta morbidade e mortalidade em ovelhas, o papel de animais silvestres no ciclo do vírus da língua azul é desconhecido. A artrite encefalite caprina (CAE) e Maedi-visna

\footnotetext{
${ }^{1}$ Received on May 22, 2017.

Accepted for publication on May 31, 2017.

2 Departamento de Medicina Veterinária, Setor de Ciências Agrárias, Universidade Federal do Paraná (UFPR), Rua dos Funcionários 1540, Cabral, Curitiba, PR 80035-050, Brazil. *Corresponding author: abiondo@ufpr.br

${ }^{3}$ Departamento de Pesquisa e Conservação da Fauna, Secretaria Municipal do Meio Ambiente, Curitiba, PR 80020-000.

${ }^{4}$ Instituto de Saúde Coletiva, Universidade Federal da Bahia (UFBA), Salvador, BA 40110-000, Brazil.

${ }^{5}$ Instituto Biológico, Centro de Pesquisa e Desenvolvimento de Sanidade Animal, São Paulo, SP 04014-000, Brazil.
}

vírus (MVV) tem sido encontrados em cabras e ovelhas, porém não há descrição em espécies selvagens. Amostras de soro de 17 aoudads (Ammotragus lervia), mantidos em cativeiro no Zoológico de Curitiba, Sul do Brasil, foram testadas para os vírus da língua azul, da artrite encefalite caprina (CAE) e Maedi-visna, utilizando imunodifusão em gel de ágar e o teste de ELISA (enzyme linked immunosorbent assay). Foram observados anticorpos para o vírus da língua azul em 35,3\% (6/17) aoudads utilizando a imunodifusão em gel de ágar e 41,2\% (7/17) no ELISA. Todas as amostras foram negativas para a presença de anticorpos contra os vírus da artrite encefalite caprina e Maedi-visna. Esses resultados indicam que os aoudads podem ser infectados pelo vírus da língua azul e atuar como um reservatório silvestre tanto em cativeiro quanto em vida livre.

TERMOS DE INDEXAÇÃO: Língua azul, artrite encefalite caprina, Maedi-Visna, aoudads, zoológico, viroses. 


\section{INTRODUCTION}

Bluetongue virus (BTV) has been classified within the Orbivirus and Reoviridae family (Coetzee et al. 2012), transmitted by Culicoides genus midges and affecting domestic and wild ruminants worldwide. The infectious and noncontagious disease has been endemic in some regions of the Middle East, Africa, Australia, the Americas and southern Europe (Yesilbag et al. 2011) and, along with caprine arthritis-encephalitis (CAE) and Maedi-Visna viruses, considered of compulsory notification according to the World Organization for Animal Health (OIE).

BTV infection has been typically associated with clinical disease in sheep and deer. However, the disease has been usually subclinical in cattle and goats (Maclachlan et al. 2009) but acute manifestations may occur in prime-exposed populations (Coetzee et al. 2012). Favorable climatic conditions for vector development (MaClachlan et al. 2009) may explain outbreaks with sheep and goats deaths reported in Brazil (Clavijo et al. 2002). In contrast, caprine arthritis-encephalitis (CAE) and Maedi-Visna viruses are mainly transmitted by contaminated tissues and therefore dissemination may be related to in-farm livestock sanity (Cruz et al. 2013).

Despite lentiviruses have reportedly surpassed host species barrier, caprine arthritis-encephalitis (CAE) has been described as viral disease usually found in goats while Maedi-visna virus often infect sheeps, both diseases with economic impacts. A relative new virus similar to small ruminants, CAE and MVV may also affect wildlife, which may predispose to emergence of new lentivirus diseases in new hosts (Cruz et al. 2013).

Barbary sheep has been genetically related to domestic goat and sheep (Mereu et al.2008), posing a sanitary threat to livestock in native areas.

All continents except Antarctica are considered endemic to bluetongue (Yesilbag et al. 2011), recently established Europe (Maclachlan et al. 2009). Although several studies have been conducted in zoos worldwide (Yesilbag et al. 2011) and bluetongue has been first reported in Africa, no clinical signs have been reported in African wildlife ruminant species, maybe due to disease resistance (Vilar et al. 2011). However, prevalence and bluetongue resistance in free-ranging Barbary sheep remains to be fully established.

Brazil has BTV, CAE and MVV circulating among the domestic small ruminants, but only bluetongue virus was detected in wildlife: tapirs (Tapirus terrestris) in Pantanal and peccaries in (Tayassu tajacu) in southeastern Brazil (Gerber et al. 2012, Medici et al. 2014).

Although non-native captive wild ruminants have been reportedly positive for BTV and may be important source of disease maintenance and spreading to livestock (Vilar et al. 2011, Ruiz-Fons et al. 2014), their epidemiological role remains unclear. Accordingly, this study aimed to evaluate the presence of antibodies against bluetongue, caprine arthritis-encephalitis (CAE) and Maedi-Visna viruses in Barbary sheep (Ammotragus lervia), an African ruminant considered vulnerable species, at Curitiba Zoo, Southern Brazil.

\section{MATERIALS AND METHODS}

All 17 clinically healthy captive-born Barbary sheep, male and females of different ages and identified by ear tags, kept on public display or in isolation area, were included in the study. Blood samples were collected under physical restraint only, and serum was separated and stored at $-20^{\circ} \mathrm{C}$ until testing. No animal has shown any clinical signs during the period of study.

Samples were tested by agar gel Immunodiffusion (AGID) and enzyme linked immunosorbent assay (ELISA) following the Pan American Health Organization (PAHO-WHO) and performed according to the manufacturer's protocol from the Centro PanAmericano de Febre Aftosa (PANAFTOSA), Duque de Caxias, Rio de Janeiro, Brazil. ELISA test solid phase competition (ELISA CFS) is based on the interruption or not of the reaction between antigen and monoclonal antibody specific serogroup by adding the problem serum. The test is able to detect antibodies against all serotypes of the BTV. The AGID detects a precipitin line agarose gel which is formed by the reaction between the antibody with soluble antigen specific group. In addition, samples were also tested by AGID for antibodies against caprine arthritis-encephalitis and Maedi-Visna viruses, according to Crawford \& Adams (1981), using CAE and MAEDI-VISNA diagnosis kits (Biovetech, Brazil). Although the antibodies have been usually detected between 14 to 28 days, AGID has been described as a qualitative technique and provide no serum titer.

Contingency tables were created and associations were tested with a non-commercial software (OpenEpi, Centers of Disease Control, Atlanta, GA, USA) (Dean et al. 2006). Prevalence ratios and 95\% confidence intervals were calculated, and Fisher's exact test was used to compare proportions between group variables at a $5 \%$ significance level. Since mean age of sampled Barbary sheep was $4.5 \pm 2.7$ years, age of the animals was dichotomized at 5 years for prevalence ratio calculations. Concordance of tests results was calculated using Kappa coefficient.

The experimental protocol was approved by Animal Use Ethics Committee of the Agricultural Sciences Campus of the Federal University of Paraná, Brazil (UFPR, protocol 045/2013).

\section{RESULTS}

A total of 6/17 (35.3\%) Barbary sheep was positive for BTV antibodies by AGID and 7/17 (41.2\%) by ELISA. Prevalence of bluetongue antibodies in $\geq 5$ year-old animals was 2.9-fold (0.7-11.5) higher by AGID and 1.9-fold (0.6-6.0) higher by ELISA, when compared to younger animals (Table 1 ). Male Barbary sheep were less likely to present anti-bluetongue virus antibodies when compared to females by AGID ( $P R=0.1$; CI $95 \%=0.0-0.9$ ) and marginally less likely when tested by ELISA (PR=0.3; CI 95\% =0.1-1.1) when compared to females. All animals presenting bluetongue virus antibodies, either by AGID or ELISA, were housed in the isolation area. All animals were seronegative for caprine arthritis-encephalitis virus (CAEV) and Maedi-Visna virus.

\section{DISCUSSION}

The bluetongue prevalence found herein of 7/17 (41.2\%) animals was similar to 6/12 (50.0\%) Barbary sheep previously reported in the USA (Hampy et al. 1979), but both were much higher than $0 / 11(0 \%)$ described with virus neutralization test in a Turkish zoo (Yesilbag et al. 2011). Although no study has been reported to date in Brazil on Barbary sheep, bluetongue seropositivity has been found in other wildlife species such as 19/49 (39.0\%) free-range native peccaries (Gerber et al. 2012) and 2.8 to $15.6 \%$ in free-range native tapirs (Medici et al. 2014). Such findings have indicated the presence of required wildlife vector and host for virus cycle (Maclachlan et al. 2009). 
Table 1. Prevalence of anti-bluetongue virus antibodies by agar gel immunodiffusion (AGID) and enzyme linked immunosorbent assay (ELISA) tests stratified by age, sex and housing location

\begin{tabular}{|c|c|c|c|c|c|c|c|c|}
\hline \multirow{2}{*}{ Characteristic } & \multicolumn{4}{|c|}{ Bluetongue virus (AGID) } & \multicolumn{4}{|c|}{ Bluetongue virus (ELISA) } \\
\hline & $\mathrm{n} / \mathrm{N}$ & $\%$ & PR (CI 95\%) & p-value * & $\mathrm{n} / \mathrm{N}$ & $\%$ & PR (CI 95\%) & p-value * \\
\hline \multicolumn{9}{|l|}{ Age } \\
\hline$<5<5$ years & $2 / 10$ & 20.0 & - & - & $3 / 10$ & 30.0 & - & - \\
\hline$\geq 5$ years & $4 / 7$ & 57.1 & $2.9(0.7-11.5)$ & 0.16 & $4 / 7$ & 57.1 & $1.9(0.6-6.0)$ & 0.35 \\
\hline \multicolumn{9}{|l|}{ Sex } \\
\hline Female & $5 / 7$ & 71.4 & - & - & $5 / 7$ & 71.4 & - & - \\
\hline Male & $1 / 10$ & 10.0 & $0.1(0.0-0.9)$ & 0.03 & $2 / 10$ & 20.0 & $0.3(0.1-1.1)$ & 0.06 \\
\hline \multicolumn{9}{|l|}{ Housing } \\
\hline Isolation & $6 / 12$ & 50.0 & - & - & $7 / 12$ & 58.3 & - & - \\
\hline Public display & $0 / 5$ & 0.0 & $\mathrm{NA}^{* *}$ & 0.10 & $0 / 5$ & 0.0 & $N A^{* *}$ & 0.04 \\
\hline
\end{tabular}

In Brazil, bluetongue has been widely diagnosed in domestic sheep with prevalence varying from $0.16 \%$ to $81.4 \%$ probably due to different climatic conditions, which may influence vector survival and propagation (Clavijo et al. 2002, Costa et al. 2006, Balaro et al. 2014). Since domestic sheep has shown high bluetongue prevalence, native and exotic wildlife may be at risk, particularly when sharing livestock common or nearby areas.

Although widely used in BTV serosurveys due to simplicity and easy antigen production, AGID test may cross-react with other Orbivirus species such as the Epizootic Hemorrhagic Disease virus - EHDV (Gerber et al. 2012) and ELISA has been recommended as BTV antibody detection test. Although test agreement was considered good (Kappa $=0.88$ ), discrepancies found herein may be attributed to different sensitivity and specificity between AGID and ELISA.

The higher bluetongue prevalence, observed in females differs from previously when males have shown higher prevalence due to natural behavior and larger body size (Rossi et al. 2014, Ruiz-Fons et al. 2014). Considering age, the average found in females was higher than in males, corroborating with a previous data in which older animals may present higher bluetongue likelihood exposure when compared to juveniles, due to behavior associated to time of exposure (Rossi et al. 2014). All animals presenting bluetongue virus antibodies were housed in the isolation area, with more proximity to the forest around the zoo. It differs from earlier studies in which exhibiting captive animals in open enclosures has a higher risk of pathogens infection (De Camps et al. 2008).

As expected, the present study found no seropositive animal for CAE and MVV, reinforcing the absence of these lentivirus detection in wildlife ruminants but not excluding similar viruses with different genomic type and antibody response (Cruz et al. 2013). Interestingly, despite Curitiba subtropical climate (annual average: $16.8^{\circ} \mathrm{C}$ of temperature, $1483.4 \mathrm{~mm}$ of rain and $80.7 \%$ of humidity), domestic sheep bluetongue outbreak was reported in 2001 with 128/130 (98.5\%) euthanized animals due to severe acute disease (Clavijo et al. 2002). Since livestock outbreaks have been reportedly related to Zoo infection (Rossi et al. 2014), presence of seropositive captive species at the Curitiba Zoo may provide a source of infection to nearby livestock including cattle, sheep and goats or vice versa to other captive and susceptive wildlife animals. Regardless the source (wildlife or domestic), a sanitary barrier (seronegative vaccination and/or euthanasia of seropositive animals) should be established in between to ensure proper animal health and vector control.

\section{CONCLUSIONS}

Our findings have demonstrated the occurrence of antibodies in captive-born Barbary sheep against bluetongue (but not caprine arthritis-encephalitis and Maedi-Visna viruses), indicating animal exposure and bluetongue virus circulation.

Absence of clinical signs in adult and captive-born animals may indicate Barbary sheep as potential resistant (and reservoir) species and could contribute to dissemination of lentiviruses in the zoo area.

\section{REFERENCES}

Balaro M.F.A., Lima M.S., Del Fava C., Oliveira G.R., Pituco E.M. \& Brandão F.Z. 2014. Outbreak of Bluetongue virus serotype 4 in dairy sheep in Rio de Janeiro, Brazil. J. Vet. Diagn. Invest. 26(4):567-570. http://dx.doi. org/10.1177/1040638714538020. PMid:24916443.

Clavijo A., Sepulveda L., Lopez J.W., Riva J., Pessoa-Silva M. \& Tailor-Ruthes A. 2002. Isolation of bluetongue virus serotype 12 from an outbreak of the disease in South America. Vet. Rec. 151(10):301-302. http://dx.doi. org/10.1136/vr.151.10.301. PMid:12243274.

Coetzee P., Stokstad M., Venter E.H., Myrmel M. \& Van Vuuren M. 2012. Bluetongue: a historical and epidemiological perspective with the emphasis on South Africa. Virol. J. 9(1):198. http://dx.doi.org/10.1186/1743422X-9-198. PMid:22973992.

Costa J.R.R., Lobato Z.I.P., Herrmann G.P., Leite R.C. \& Haddad J.P.A. 2006. Prevalência de anticorpos contra o vírus da língua azul em bovinos e ovinos do Sudoeste e Sudeste do Rio Grande do Sul. Arq. Bras. Med. Vet. Zootec. 58(2):273-275. http://dx.doi.org/10.1590/S0102-09352006000200017.

Crawford T.B. \& Adams D.S. 1981. Caprine arthritis-encephalitis: clinical features and presence of antibody in selected populations. J. Am. Vet. Med. Assoc. 178(7):713-719. PMid:6259112.

Cruz J.C.M., Singh D.K., Lamara A. \& Chebloune Y. 2013. Small ruminant lentiviruses (SRLVs) break the species barrier to acquire new host range. Viruses 5(7):1867-1884. http://dx.doi.org/10.3390/v5071867. PMid:23881276. 
Dean A.G., Sullivan K.M. \& Soe M.M. 2006. OpenEpi: open source epidemiologic statistics for public health, version. Available at <http://www.OpenEpi. com>. Access on Apr. 6, 2013.

De Camps S., Dubey J.P. \& Saville W.J. 2008. Seroepidemiology of Toxoplasma gondii in zoo animals in selected zoos in the midwestern United States. J. Parasitol. 94(3):648-653. http://dx.doi.org/10.1645/GE-1453R.1. PMid:18605803.

Gerber P.F., Galinari G.C.F., Cortez A., Paula C.D., Lobato Z.I.P. \& Heinemann M.B. 2012. Orbivirus infections in collared peccaries (Tayassu tajacu) in southeastern Brazil. J. Wildl. Dis. 48(1):230-232. http://dx.doi. org/10.7589/0090-3558-48.1.230. PMid:22247399.

Hampy B., Pence D.B. \& Simpson C.D. 1979. Serological studies on sympatric Barbary sheep and mule deer from Palo Duro Canyon, Texas. J. Wildl. Dis. 15(3):443-446. http://dx.doi.org/10.7589/0090-3558-15.3.443. PMid:228088.

Maclachlan N.J., Drew C.P., Darpel K.E. \& Worwa G. 2009. The pathology and pathogenesis of bluetongue. J. Comp. Pathol. 141(1):1-16. http://dx.doi. org/10.1016/j.jcpa.2009.04.003. PMid:19476953.

Medici E.P., Mangini P.R. \& Fernandes-Santos R.C. 2014. Health assessment of wild lowland tapir (tapirus terrestris) populations in the atlantic forest and pantanal biomes, Brazil (1996-2012). J. Wildl. Dis. 50(4):817-828. http://dx.doi.org/10.7589/2014-02-029. PMid:25105810.

Mereu P., Palici di Suni M., Manca L. \& Masala B. 2008. Complete nucleotide mtDNA sequence of Barbary sheep (Ammotragus lervia). DNA Seq. 19(3):241245. http://dx.doi.org/10.1080/10425170701550599. PMid:17852329.

Rossi S., Pioz M., Beard E., Durand B., Gibert P., Gauthier D., Klein F., Maillard D., Saint-Andrieux C., Saubusse T. \& Hars J. 2014. Bluetongue dynamics in French wildlife: exploring the driving forces. Transbound Emerg. Dis. 61(6):12-24. http://dx.doi.org/10.1111/tbed.12061. PMid:23414427.

Ruiz-Fons F., Sánchez-Matamoros A., Gortázar C. \& Sánchez-Vizcaíno J.M. 2014. The role of wildlife in bluetongue virus maintenance in Europe: lessons learned after the natural infection in Spain. Virus Res. 182:50-58. http:// dx.doi.org/10.1016/j.virusres.2013.12.031. PMid:24394295.

Vilar M.J., Guis H., Krzywinski J., Sanderson S. \& Baylis M. 2011. Culicoides vectors of bluetongue virus in Chester Zoo. Vet. Rec. 168(9):242. http:// dx.doi.org/10.1136/vr.c6684

Yesilbag K., Alpay G. \& Karakuzulu H. 2011. A serologic survey of viral infections in captive ungulates in Turkish zoos. J. Zoo Wildl. Med. 42(1):44-48. http:// dx.doi.org/10.1638/2010-0009.1. PMid:22946369. 